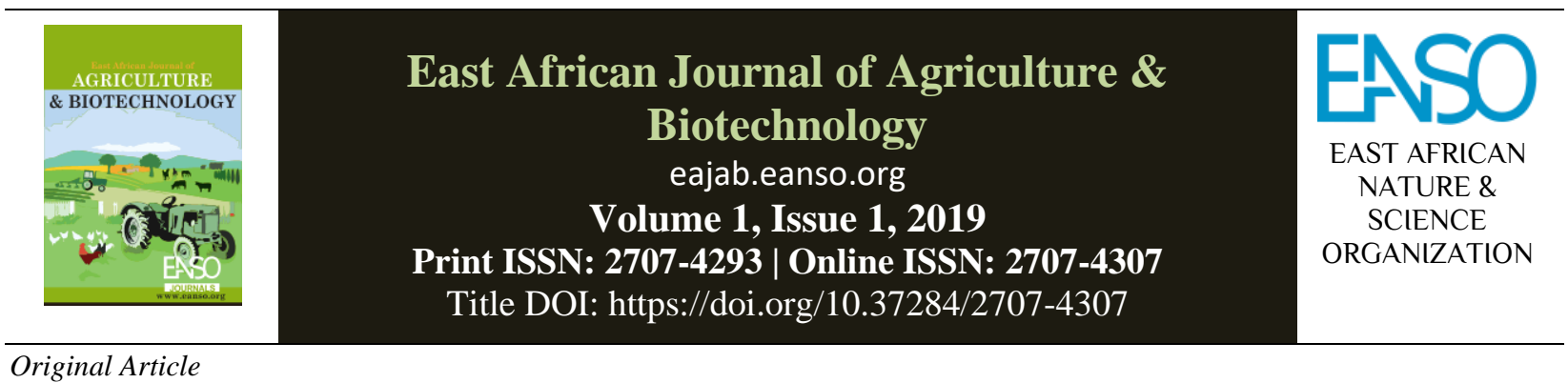

\title{
Effect of Spider Plant Accessions on Phenotypic Traits: Implications for Breeders and Farmers in Kenya
}

\section{Kenneth Mutoro}

Jomo Kenyatta University of Agriculture and Technology, P.O. Box 62000 - 00200, Nairobi, Kenya, kenmutoro@yahoo.com

Article DOI: https://doi.org/10.37284/eajab.1.1.16

\section{Article history:}

Received: 16 Jul 2019

Accepted: 23 Jul 2019

Published: 30 Jul 2019

Keywords:

Phenotypic diversity, African leafy vegetable, Cleome gynandra, genotypes

\begin{abstract}
Spider plant (Cleome gynandra L.) is an important African leafy vegetable (ALV) that has been used by local African communities as a source of nutrition in their diets for many years. The plant has recently attracted an increasing demand for its highly nutritive and health-promoting bioactive compounds important in combating malnutrition and reducing human degenerative diseases. Despite the great value of the spider plant, its supply and cultivation remain low, a factor attributed to unavailability of superior genotypes. This study carried out at Ruiru Sub-county, Kiambu County in Kenya sought to establish the influence of genotypic variation on spider plant phenotypic diversity for future breeding and conservations. Experimental plots were set up in the field in Ruiru using split-plot design with three replications. Analysis of variance (ANOVA) was used to assess the significance of variables. Results indicated that genotypes MLSF3, UGSF36, UGSF14, and MLSF17 produced the highest number of flowers, large petioles, big stem sizes and large leaf area respectively. In conclusion, the study recommends the adoption of genotypes MLSF17, UGSF14, UGSF36 and MLSF3 by farmers considering their outstanding positive effect on phenotypic traits.
\end{abstract}

\section{ACKNOWLEDGEMENT}

I wish to sincerely acknowledge the National Council of Science, Technology and Innovation for funding the project. Also, Jomo Kenyatta University of Agriculture and Technology Department of Horticulture and Food Security for providing land for trials and laboratory facilities. Finally, World Vegetable Centre, (Arusha, Tanzania), for providing the spider plant seed accessions.

\section{HOW TO CITE}

Mutoro, K. (2019). Effect of Spider Plant Accessions on Phenotypic Traits: Implications for Breeders and Farmers in Kenya. East African Journal of Agriculture and Biotechnology, 1(1), 1-6. https://doi.org/10.37284/eajab.1.1.16 


\section{INTRODUCTION}

Knowledge on phenotypic diversity of the existing spider plant accessions is a milestone in the improvement of spider plant supply and cultivation. The spider plant is a highly nutritious indigenous vegetable in Kenya. Agriculture is the mainstay of Kenya's economy providing the basis of development for other sectors of the economy. The Agricultural sector contributes about $30 \%$ of the gross domestic product and accounts for over $75 \%$ of the total labour force (MoA, 2017). It is envisaged that the sector will continue to play a leading role in stimulating and supporting the country's economic growth mainly through the vibrant horticulture industry (HCDA, 2014). According to the Horticultural Crops Development Authority of Kenya (HCDA, 2014), vegetables contributed over $40 \%$ of the total value of horticultural production between 2011 and 2013. Thirty percent $(30 \%)$ of the vegetables valued at USD 247 million were exported mainly to the European Union (HCDA, 2014).

In recent times, African leafy vegetable (ALVs) are increasingly playing a central role in the horticulture sector. The percentage contribution of ALV such as cowpeas, African nightshades, vegetable amaranths, jute mallow and spider plant has been remarkably rising; their value in the domestic market in Kenya rose from $4.3 \%$ in 2011 to $5 \%$ in 2013 (HCDA, 2014). The area under these vegetables has also increased over the years from 31,864 ha in 2011 to over 40,000 ha in 2013 leading to a production increase from 31,868 MT in 2011 to $178,268 \mathrm{MT}$ in 2013 (HCDA, 2014). The ALVs has several advantages over other exotic vegetables. They have high nutritive value (Chweya \& Mnzava, 1997), medicinal value and health benefits (Kokwaro, 2009; Olembo et al., 1995; and De Albuquerque et al., 2007). These ALVs are also important in conserving a rich diversity of genotypes of importance for future generations and breeding (Chadha, 2003).

Cleome gynandra (L.) is among the most important traditional leafy vegetables widely used in Africa (Schippers, 2000). In English, Cleome gynandra is commonly known as spider flower or plant, cats' whiskers, spider wisp, and African cabbage. This tropical plant has different names among the
African dialects. Among the different Cleome species, Cleome gynandra is the most widely used as a leafy vegetable but Cleome monophylla and Cleome hirta, which are close relatives, are also used occasionally (Vorster et al., 2005). The spider plant is used as both food and medicine. Van Rensburg et al. (2004) also noted that ALVs are rich in micronutrients and vitamins hence could play an important role in alleviating hunger and malnutrition. The plant has been evaluated for nutrient content and showed to have high values especially for calcium, magnesium, iron, zinc, vitamin A, C and E (Chweya \& Mnzava, 1997), making it suitable for combating malnutrition and lifestyle diseases especially in Sub-Saharan Africa (Van Jaarsveld et al., 2014; Van Rensburg et al., 2004). There are a number of genetically diverse populations among spider plant accessions, but it is not clear to what extent they are genetically different (K'Opondo, Muasya \& Kiplagat, 2005; Maundu et al., 1999; Wasonga, 2014).

\section{MATERIALS AND METHODS}

Field trials were carried out in order to evaluate, select and document spider plant varieties, which included P6, MLSF17, MLSF3, UGSF9, UGSF12, UGSF14, UGSF25, UGSF36, and IP3. Field experiments were conducted in Ruiru District situated in Central Province, Kenya, between March - June 2011 and April - July 2012. The geographical coordinates of the study site are latitude $1^{\circ} 9^{\prime} 0^{\prime \prime} \mathrm{S}$, and longitude $36^{\circ} 58^{\prime} 0^{\prime \prime} \mathrm{E}$. The area is classified under sub-tropical highland climate, by Köppen climate classification system and receives an average annual rainfall of 1,025 $\mathrm{mm}$. Temperature range is $10-26{ }^{\circ} \mathrm{C}$ with an altitude of $1,795 \mathrm{~m}$ above sea level. The soils are typically red on undulating topography. Main human activities include coffee farming, dairy, and horticulture (MoA, 2017). The experimental factors tested consisted of both qualitative and quantitative traits. The traits included the number of flowers, size of petioles, stem size and leaf area. The experiment was laid out as a split-plot design with three replications. Analyses of variance (ANOVA) were done using SAS (SAS 9.1.3) for dry weight, leaf area, height and number of leaves. The level of significance was at $\mathrm{p}<5 \%$ and mean separation was done using LSD. 


\section{RESULTS}

\section{Influence of Spider Plant Genotype on the Number of Flowers}

There was a significant difference among genotypes in Ruiru trials. Genotypes significantly influenced $(\mathrm{P} \leq 0.05)$ the number of flowers across different harvesting periods during the long rainy season (Table 1). In the first harvesting period (seven weeks after crop establishment), there was no significant difference in the number of flowers among the various genotypes $(\mathrm{P} \leq 0.05)$. The probable attribution to this insignificance could be because the plant at seven weeks has not attained its full growth potential to express all genotypic traits inherent within MLSF3 and UGSF36 significantly produced the highest number of flowers compared to all other genotypes in the tenth week of harvesting period $(\mathrm{P} \leq 0.05)$. Similarly, UGSF9, UGSF25 and UGSF14 significantly produced more flowers than IP3, P6 (control) and MLSF17 in the tenth. There was no significant difference between the number of flowers produced in the second season at the seventh and tenth week of harvesting (Table 1). The depletion of micronutrients in the soil by the first crop necessary for inducing flower formation by spider plant could be the probable cause for few flowers in the second season establishment. The high number of flowers produced by MLSF3 and UGSF36 implies that the genomes are best suited for use as a source of seed for multiplication purposes. Furthermore, it attracts flower-visiting insects that are pivotal to both natural and agricultural ecosystems (Kevan, 1990). Furthermore, a good variety for further value addition on spider plant seeds by farmers for agribusiness.

Table 1: Effect of spider plant genotype on the number of flowers of spider plant across different harvesting periods in Ruiru season one and two

\begin{tabular}{|c|c|c|c|c|}
\hline \multirow{3}{*}{ Genotype } & \multicolumn{4}{|c|}{ Harvesting period in weeks } \\
\hline & \multicolumn{2}{|c|}{ Season One } & \multicolumn{2}{|c|}{ Season Two } \\
\hline & 7 & 10 & 7 & 10 \\
\hline P6 & $0.1133 \mathrm{a}$ & $2.24 b c$ & $0.0611 \mathrm{a}$ & $2.524 \mathrm{a}$ \\
\hline MLSF17 & $0.2122 \mathrm{a}$ & $1.441 \mathrm{c}$ & $0.0511 \mathrm{a}$ & $1.603 \mathrm{a}$ \\
\hline MLSF3 & $0.2033 a$ & $4.693 \mathrm{a}$ & $0.1011 \mathrm{a}$ & $2.339 \mathrm{a}$ \\
\hline UGSF9 & $0.1144 \mathrm{a}$ & $3.638 \mathrm{ab}$ & $0.0644 \mathrm{a}$ & $2.522 \mathrm{a}$ \\
\hline UGSF12 & $0.1944 \mathrm{a}$ & $1.064 \mathrm{a}$ & $0.0633 \mathrm{a}$ & $1.807 \mathrm{a}$ \\
\hline UGSF25 & $0.17 \mathrm{a}$ & $3.74 \mathrm{ab}$ & $1.0022 \mathrm{a}$ & $1.928 \mathrm{a}$ \\
\hline UGSF36 & $0.1056 \mathrm{a}$ & $4.969 \mathrm{a}$ & $0.0267 \mathrm{a}$ & $1.576 \mathrm{a}$ \\
\hline IP3 & $0.2233 a$ & $2.611 b c$ & $0.0178 \mathrm{a}$ & $2.433 \mathrm{a}$ \\
\hline UGSF14 & $0.0911 \mathrm{a}$ & 3.994ab & $0.01 \mathrm{a}$ & $1.897 \mathrm{a}$ \\
\hline LSD & 0.1423 & 1.12 & 0.951 & 0.8449 \\
\hline CV\% & 34.9 & 2.7 & 119.2 & 32.1 \\
\hline
\end{tabular}

Means in the same column followed by different letter $(s)$ are significantly different at $P<0.005$

\section{Effect of Spider Plant Genotype on the Size of Petioles of Spider}

There was a significant difference among genotypes on the size of petioles in Ruiru during season one. Genotypes significantly influenced $(\mathrm{P} \leq$ $0.05)$ the size of petioles across different harvesting periods in the long rain season (Table 2). In the seventh week, the sizes of petioles were not significantly different between various genomes.
However, in the tenth week, there was significant difference in the size of petioles among different spider plant accessions. UGSF14 and UGSF36 produced significantly bigger petioles compared to all other accessions. The size of petioles has an influence on the size of leaves and hence the ultimate yields of the plant. In the second season, there was no significant difference in the size of petioles of spider plant both across and within harvesting periods. 
East African Journal of Agriculture and Biotechnology, 1(1), 2019

Article DOI: https://doi.org/10.37284/eajab.1.1.16

Table 2: Effect of spider plant genotype on the size of petioles of spider plant across different harvesting periods in Ruiru season one and two

\begin{tabular}{|c|c|c|c|c|}
\hline \multirow{3}{*}{ Genotype } & \multicolumn{4}{|c|}{ Harvesting period in weeks } \\
\hline & \multicolumn{2}{|c|}{ Season One } & \multicolumn{2}{|c|}{ Season Two } \\
\hline & 7 & 10 & 7 & 10 \\
\hline P6 & $0.2778 \mathrm{a}$ & $0.7911 \mathrm{ab}$ & $0.2711 \mathrm{a}$ & $1.217 \mathrm{a}$ \\
\hline MLSF17 & $0.2644 \mathrm{a}$ & $0.7356 a b$ & $0.2467 \mathrm{a}$ & $1.059 \mathrm{a}$ \\
\hline MLSF3 & $0.37 \mathrm{a}$ & $0.6289 \mathrm{ab}$ & $0.3711 \mathrm{a}$ & $1.227 \mathrm{a}$ \\
\hline UGSF9 & $0.2067 \mathrm{a}$ & $0.9189 \mathrm{ab}$ & $0.1711 \mathrm{a}$ & $1.118 \mathrm{a}$ \\
\hline UGSF12 & $0.2178 \mathrm{a}$ & $0.9 \mathrm{ab}$ & $0.22 \mathrm{a}$ & $1.157 \mathrm{a}$ \\
\hline UGSF25 & $0.2367 \mathrm{a}$ & $0.8556 \mathrm{ab}$ & $0.2433 \mathrm{a}$ & $1.163 \mathrm{a}$ \\
\hline UGSF36 & $0.3022 \mathrm{a}$ & $1.0411 \mathrm{a}$ & $0.3278 \mathrm{a}$ & $1.153 \mathrm{a}$ \\
\hline IP3 & $0.2556 \mathrm{a}$ & $0.4322 b$ & $0.1922 \mathrm{a}$ & $1.053 \mathrm{a}$ \\
\hline UGSF14 & $0.2333 \mathrm{a}$ & $1.0278 \mathrm{a}$ & $0.1944 \mathrm{a}$ & $0.936 \mathrm{a}$ \\
\hline LSD & 0.1565 & 0.308 & 0.1578 & 0.3765 \\
\hline CV\% & 10.5 & 19.6 & 44.8 & 23 \\
\hline
\end{tabular}

Means in a same column followed by different letter ( $s$ ) are significantly different at $P<0.005$

\section{Effect of Spider Plant Genotype on the Size of Stem}

Genotypic variation in spider plants significantly influenced $(\mathrm{P} \leq 0.05)$ the size of stems across different harvesting periods in Ruiru (Table 3). Results indicated that UGSF14 produced bigger stems per plant than all other genotypes in the tenth week of harvesting (see Table 3). IP3 produced the least stem size of all the genotypes tested (Table 3). There were no significant differences in the size of stem per plant as a result of genotypic variation in the seventh week of harvesting. Similarly, for the greenhouse, the aboveground diurnal temperature ranged from $15-37^{\circ} \mathrm{C}$ for the first season and 11 $31^{\circ} \mathrm{C}$ for the second season. The greenhouse plants began to flower five weeks after planting compared to outdoor that started flowering later in week six. Similar observations were made in the second season where there was no significant differences in stem size in the seventh week of harvesting among genotypes. Nevertheless, MLSF17 produced the biggest stem size compared to all other genotypes in the tenth week of harvesting (Table 3.3). However, the difference between UGSF14 and MLSF17 was not significantly different in the second season.

Table 3: Effect of genotype on the size of the stem of spider plant across different harvesting periods in Ruiru season one and two

\begin{tabular}{lllll}
\hline Genotype & \multicolumn{2}{l}{$\begin{array}{l}\text { Harvesting period in weeks } \\
\text { Season One }\end{array}$} & \multicolumn{1}{l}{ Season two } & $\mathbf{1 0}$ \\
\hline P6 & $\mathbf{7}$ & $4.36 \mathrm{~cd}$ & $0.8022 \mathrm{a}$ & $1.799 \mathrm{ab}$ \\
MLSF17 & $1.018 \mathrm{a}$ & $4.669 \mathrm{bc}$ & $1.0889 \mathrm{a}$ & $2.682 \mathrm{a}$ \\
MLSF3 & $1.187 \mathrm{a}$ & $5.792 \mathrm{abc}$ & $0.8211 \mathrm{a}$ & $2.203 \mathrm{ab}$ \\
UGSF9 & $1.046 \mathrm{a}$ & $4.294 \mathrm{~cd}$ & $0.77 \mathrm{a}$ & $2.226 \mathrm{ab}$ \\
UGSF12 & $1.001 \mathrm{a}$ & $4.449 \mathrm{~cd}$ & $0.9322 \mathrm{a}$ & $2.181 \mathrm{ab}$ \\
UGSF25 & $1.131 \mathrm{a}$ & $4.618 \mathrm{bcd}$ & $0.7933 \mathrm{a}$ & $2.544 \mathrm{ab}$ \\
UGSF36 & $1.066 \mathrm{a}$ & $6.166 \mathrm{ab}$ & $0.7278 \mathrm{a}$ & $2.221 \mathrm{ab}$ \\
IP3 & $1.279 \mathrm{a}$ & $3.029 \mathrm{~d}$ & $0.5989 \mathrm{a}$ & $1.627 \mathrm{~b}$ \\
UGSF14 & $0.977 \mathrm{a}$ & $6.887 \mathrm{a}$ & $0.5889 \mathrm{a}$ & $2.202 \mathrm{ab}$ \\
\hline LSD & $1.174 \mathrm{a}$ & $\mathbf{1 . 0 1 2}$ & $\mathbf{0 . 4 0 3}$ & $\mathbf{0 . 6 5 4 4}$ \\
CV\% & $\mathbf{0 . 5 1 1 4}$ & $\mathbf{1 1 . 5}$ & $\mathbf{1 8 . 3}$ & $\mathbf{1 6 . 1}$ \\
\hline
\end{tabular}

Means in a same column followed by different letter $(s)$ are significantly different at $P<0.005$ 
East African Journal of Agriculture and Biotechnology, 1(1), 2019

Article DOI: https://doi.org/10.37284/eajab.1.1.16

\section{Effect of Genotype on the Leaf Area of Spider Plant}

Genotypic variation significantly $(\mathrm{P}<0.005)$ affects leaf area of spider plant across different harvesting periods (Table 3.4). In the seventh week of harvesting, P6 and MLSF17 produced the largest leaf area than all other genotypes whereas, in the ninth and tenth week of harvesting, IP3 and MLSF17 had the biggest leaf area respectively compared to all other genotypes. Genotypes UGSF12 and UGSF25 had the least leaf area among all genotypes.

Table 4: Effect of genotype on the leaf area of spider plant across different harvesting periods in Ruiru

\begin{tabular}{llll}
\hline Genotype & \multicolumn{2}{l}{ Harvesting period in weeks } & $\mathbf{1 0}$ \\
& $\mathbf{7}$ & $\mathbf{9}$ & $1167 \mathrm{ab}$ \\
P6 & $251.5 \mathrm{a}$ & $923 \mathrm{ab}$ & $1281 \mathrm{a}$ \\
MLSF17 & $217.3 \mathrm{a}$ & $1033.4 \mathrm{ab}$ & $1153 \mathrm{ab}$ \\
MLSF3 & $183 \mathrm{~b}$ & $1012.3 \mathrm{ab}$ & $1059 \mathrm{ab}$ \\
UGSF9 & $223.4 \mathrm{ab}$ & $924.7 \mathrm{ab}$ & $1138 \mathrm{ab}$ \\
UGSF12 & $174.8 \mathrm{~b}$ & $961.7 \mathrm{ab}$ & $971 \mathrm{~b}$ \\
UGSF25 & $202.1 \mathrm{ab}$ & $798.6 \mathrm{~b}$ & $1148 \mathrm{ab}$ \\
UGSF36 & $218.6 \mathrm{ab}$ & $899.6 \mathrm{ab}$ & $1205 \mathrm{ab}$ \\
IP3 & $192.3 \mathrm{ab}$ & $1085.1 \mathrm{a}$ & $1222 \mathrm{ab}$ \\
UGSF14 & $237 \mathrm{ab}$ & $892.3 \mathrm{ab}$ & $\mathbf{1 7 . 5}$ \\
\hline LSD & $\mathbf{4 0 . 7}$ & $\mathbf{1 6 8 . 8}$ & $\mathbf{8 . 5}$ \\
CV\% & $\mathbf{2 . 3}$ & $\mathbf{1 4 . 2}$ & $\mathrm{a}$ \\
\hline
\end{tabular}

Means in a same column followed by different letter $(s)$ are significantly different at $P<0.005$

\section{CONCLUSION AND RECOMMENDATIONS}

Spider plant accessions significantly influence both qualitative and quantitative traits of the crop. MLSF3 and UGSF36 produced more flowers than all other genotypes. Phenotypically, the size of petioles depended much on the type of genotype used. Large petiole sizes were produced by UGSF14 and UGSF36, while all other genotypes evaluated produced smaller petiole sizes in both seasons. Similarly, stem sizes depended on the genotype used and UGSF14 produced big stem plants compared to all other genotypes. The findings corroborate the study by Lemaire et al. (1992), that there is a positive quantitative correlation of dry matter partitioning among stems and leaf size on Lucerne (Medicago sativa). Similarly, for short-season crops such as spider plant, planting heavier seed-genotypes is advantageous since they establish faster (Houssard and Escarré, 1991). IP3 and MLSF17 produced big leaf area compared to all other genotypes evaluated. Young stems, petioles and flowers are edible and contribute significantly to the overall yield of spider plant. In conclusion, the study recommends adoption of genotypes MLSF17, UGSF14, UGSF36 and MLSF3 by farmers considering their outstanding positive effect on phenotypic traits of leaf area, number of flowers, size of petioles and stem size. Furthermore, the same genotypes should be considered for future selection and improvement by both farmers and breeders.

\section{REFERENCES}

Chadha, M. L. (2003). AVRDC's experiences within marketing of indigenous vegetables $-a$ case study on commercialization of African Eggplant.

Chweya, J. A., \& Mnzava, N. A. (1997). Cat's whiskers, Cleome gynandra L: Promoting the conservation and use of underutilized and neglected crops. Rome, Italy: Institute of Plant Genetics and Crop Plant Research, Gatersleben/IPGRI.

De Albuquerque, U. P., De Medeiros, P. M., De Almeida, A. L. S., Monteiro, J. M., Neto, E. M. D. F. L., de Melo, J. G., \& Dos Santos, J. P. (2007). Medicinal plants of the caatinga 
(semi-arid) vegetation of NE Brazil: a quantitative approach. Journal of ethnopharmacology, 114(3), 325-354.

HCDA. (2014). Horticulture Data 2012-2013 Validation Report. Nairobi, Kenya: Horticultural Crops Directorate.

Houssard, C., \& Escarré, J. (1991). The effects of seed weight on growth and competitive ability of Rumex acetosella from two successional old-fields. Oecologia, 86(2), 236-242.

Kevan, P. G. (1990, August). Pollination: keystone process in sustainable global productivity. In VI International Symposium on Pollination 288 (pp. 103-110).

Kokwaro, J. O. (2009). Medicinal Plants of East Africa (Third Edition). Nairobi, KE: University of Nairobi Press.

K'opondo, F. B. O., Muasya, R. M., \& Kiplagat, O. K. (2005). A review on the seed production and handling of indigenous vegetables (Spider plant, Jute mallow, and African nightshade complex). In Proceedings of the third Horticulture Workshop on Sustainable Horticultural Production in the Tropics (pp. 42-48). Maseno: Maseno University.

Lemaire, G., Khaity, M., Onillon, B., Allirand, J.M., Charter, M. and Gosse, G. (1992). Dynamics of Accumulation and Partitioning of $\mathrm{N}$ in Leaves, Stems and Roots of Lucerne (Medicago sativa L.) in a Dense Canopy. Annals of Botany, 70(5), 429-435. Doi: https://doi.org/10.1093/oxfordjournals.aob.a08 8499

Maundu, P.M., Njiro, E.N., Chweya, J.A., Imungi, J.K., Seme, E.N. (1999). Kenya. In Chweya, J.A. and Eyzaguirre, P.B. (Eds), The biodiversity of traditional leafy vegetables ( $\mathrm{pp}$. 51-84). Rome, Italy: International Plant Genetic Resources Institute

Mnzava, N.A. and Schippers, R.R. (2004). Brassica carinata A. Braun. In: Grubben, G. J. H., \& Denton, O. A. (Eds), Plant resources of tropical Africa 2. Vegetables (pp. 119-123). Wageningen, Netherlands: PROTA Foundation.
Ministry of Agriculture of Kenya (MoA). Annual report, 2017. www.kilimo.go.ke.

Olembo, N. K., Fedha, S.S. and Ngaira, E.S. (1995). Medicinal and Agricultural Plants of Ikolomani, Kakamega District, Kenya: Nairobi, KE: Signal Press Publishers.

Schippers, R. R. (2000). African indigenous vegetables: An overview of the cultivated species. Chatham, UK: Natural Resources Institute/ACP-EU Technical Centre for Agricultural Rural Cooperation, pp. 25-31.

Van Jaarsveld, P., Faber, M., Van Heerden, I., Wenhold, F., van Rensburg, W. J., \& Van Averbeke, W. (2014). Nutrient content of eight African leafy vegetables and their potential contribution to dietary reference intakes. Journal of food composition and analysis, 33(1), 77-84.

Van Rensburg, W. J., Venter, S. L., Netshiluvhi, T. R., Van Den Heever, E., Vorster, H. J., De Ronde, J. A., \& Bornman, C. H. (2004). Role of indigenous leafy vegetables in combating hunger and malnutrition. South African Journal of Botany, 70(1), 52-59.

Vorster, H. J., \& Jansen Van Rensburg, W. S. (2005). Traditional vegetables as a source of food in South Africa: Some experiences. In African Crop Science Conference Proceedings (pp. 669-671).

Wasonga, D. O. (2014). Phenotypic characterization of Kenyan and South African spider plant (Cleome gynandra L.) ecotypes (Doctoral Thesis). Nairobi, KE: University of Nairobi. 